\title{
The Cover Depth Effect on Corrosion-Induced Deterioration of Reinforced Concrete Focusing on Water Penetration: Field Survey and Laboratory Study
}

\author{
Shingo Asamoto ${ }^{1, *}$, Junya Sato ${ }^{2}$, Shinichiro Okazaki ${ }^{3} \mathbb{C}$, Pang-jo Chun ${ }^{4}$, Raktipong Sahamitmongkol ${ }^{5}$ \\ and Giang Hoang Nguyen 6 (D)
}

Citation: Asamoto, S.; Sato, J.;

Okazaki, S.; Chun, P.-j.;

Sahamitmongkol, R.; Nguyen, G.H.

The Cover Depth Effect on

Corrosion-Induced Deterioration of

Reinforced Concrete Focusing on

Water Penetration: Field Survey and Laboratory Study. Materials 2021, 14, 3478. https://doi.org/10.3390/ ma14133478

Academic Editors: David M. Bastidas and Jose M. Bastidas

Received: 27 May 2021

Accepted: 16 June 2021

Published: 22 June 2021

Publisher's Note: MDPI stays neutral with regard to jurisdictional claims in published maps and institutional affiliations.

Copyright: (c) 2021 by the authors. Licensee MDPI, Basel, Switzerland. This article is an open access article distributed under the terms and conditions of the Creative Commons Attribution (CC BY) license (https:// creativecommons.org/licenses/by/ $4.0 /)$.
1 Department of Civil and Environmental Engineering, Saitama University, Saitama 338-8570, Japan

Consulting Headquarters, Yachiyo Engineering Co., Ltd., Tokyo 111-8648, Japan; jn-sato@yachiyo-eng.co.jp

3 Faculty of Engineering and Design, Kagawa University, Takamatsu 761-0396, Japan; okazaki.shinichiro@kagawa-u.ac.jp

4 Institute of Engineering Innovation, School of Engineering, The University of Tokyo, Tokyo 113-8656, Japan; chun@g.ecc.u-tokyo.ac.jp

5 Department of Civil Engineering, King Mongkut's University of Technology Thonburi, Bangkok 10140, Thailand; Raktipong.sah@kmutt.ac.th

6 Inspection and Maintenance Division, National University of Civil Engineering, Hanoi 11616, Vietnam; giangnh@nuce.edu.vn

* Correspondence: asamoto@mail.saitama-u.ac.jp

\begin{abstract}
Reinforced concrete bridges were visually surveyed in Japan, Thailand, and Vietnam to study the deterioration caused by internal steel corrosion under different climates, focusing on the concrete cover depth. Spalling or cracking arising from corrosion is likely where water is supplied. According to prior studies and our surveys, a concrete cover depth of more than $40 \mathrm{~mm}$ was found to prevent spalling, regardless of environmental conditions and structure age. Because water supply at steel is a key corrosion factor, it was hypothesised that under natural conditions, the water penetration in concrete would remain at a depth of approximately $40 \mathrm{~mm}$. Our laboratory study examined water penetration under drying and wetting conditions. The results also suggested that under periodic rainfall conditions, the threshold of water penetration was not exceeded. The numerical study indicated maximum moisture evaporation to facilitate oxygen diffusion occurred at a depth of approximately 30-40 mm unless the concrete was exposed to continuous drying for more than one month. It was experimentally and numerically concluded that an adequate cover depth of greater than $40 \mathrm{~mm}$ could inhibit moisture and oxygen penetration at the steel, which supported the survey findings of cover depth effect on a high resistance to corrosion-induced deterioration despite an increase in service life.
\end{abstract}

Keywords: reinforced concrete bridge; reinforcement corrosion; corrosion-induce deterioration; water penetration; cover depth; drying and wetting conditions

\section{Introduction}

Steel corrosion in reinforced concrete structures is critical to structural performance and also causes spalling of concrete cover, which poses a risk to occupants and any other person passing under the structure. It is well established that corrosion is initiated after the depassivation of the steel surface caused by the carbonation of the cover concrete and chloride ingress. In practical design, the risk of corrosion is generally assessed based on the carbonation rate and chloride diffusion to determine the design cover depth [1-3]. The supply of both water and oxygen is necessary for the initiation of corrosion after depassivation. Tuutti [4] investigated the effect of relative humidity (hereafter referred to as " $\mathrm{RH}^{\prime \prime}$ ) during the propagation stage of corrosion, considering chloride ingress and diffusion of $\mathrm{O}_{2}$, and observed a lower corrosion rate in carbonated concrete with a decreased RH. Similarly, 
Gonzalez et al. [5] reported an environment with a low RH (50\%) can limit the corrosion rate even when carbonation occurs and chloride ions are present in the mortar. Furthermore, Glass et al. [6] concluded that high RH and chloride presence significantly increased the risk of corrosion in carbonated mortars. Moreover, Stefanoni et al. [7] summarised the key factors affecting the corrosion rate of reinforcement in carbonated concrete and concluded that the most important parameter for steel corrosion is the exposure condition, which changes the pore saturation.

It has been classically known that carbonation is one of the keys to initiate corrosion. For real structures in the field, it has been reported that corrosion was unlikely to be observed when the concrete was directly kept from moisture exposure, even when carbonation reached the reinforcing steel; however, corrosion can occur because of rainfall moisture and other sources [8,9]. Ishibashi et al. [10] and Maehara and Iyoda [11] reported that moisture supply is more likely to cause spalling in reinforced concrete. In Japan, the effect of water penetration on corrosion has been considered [12,13], along with carbonation assessment in the design specifications to utilise blended cement, reported to have a higher carbonation rate than concrete without mineral admixtures [14-16]. The simple design water penetration rate determined by the water-to-binder ratio, which is proportional to the square root of time based on the Lucas-Washburn equation, is used to calculate the penetration, assuming short-term penetration in a practical way $[12,13]$. The design cover depth to prevent corrosion in service life is determined by taking into account the age when water penetrates the steel position, as well as the carbonation progress and chloride ingress.

It is known that the total water uptake in unsaturated concrete is initially proportional to the square root of the elapsed time, but it is gradually retarded [17], which is also observed in porous materials other than cementitious materials [18]. Recently, McDonald et al. [19] explained the anomalous water sorption in cement pastes by considering the dynamic porosity based on the $1 \mathrm{H}$ nuclear magnetic resonance results, and the proposed mechanism was verified by a transport model in three types of pores with a variable porosity fraction according to the water saturation. Previous studies have shown the effect of water infiltration on corrosion in reinforced concrete for both laboratory specimens and real structures; however, the infiltration mechanism in concrete is anomalous, leading to difficulty in determining the moisture behaviour in concrete, especially under outdoor drying and wetting conditions.

In reality, because the water penetration rate can be affected by climate, such as ambient temperature and precipitation, the effect of cover depth on the deterioration of reinforced concrete by corrosion with water penetration in tropical regions can be different from that reported in Japan. In addition, the water penetration is gradually retarded, as reported previously, which might prohibit water from penetrating deeply. Hence, the objective of this study is to examine and compare the effect of cover depth on the deterioration of reinforced bridges by steel corrosion under different climate environments in Japan, Thailand, and Vietnam. The concrete cover depth was measured using a nondestructive method focusing on the spalling or cracking caused by the corrosion of the internal reinforcement. Subsequently, one-dimensional water penetration in concrete with different cover depths under drying and wetting conditions was experimentally studied, and an experimental method was proposed to focus on the electivity change before and after wetting at each depth. The experimental results are also discussed based on the numerical analysis of the drying process in the capillary and gel pores. The significance of this study is to survey the cover depth effect on corrosion-induced deterioration on-site in different Asian countries focusing on the water penetration rather than the classical corrosion factors, such as carbonation and chloride ingress, and then to experimentally and numerically investigate the threshold of water penetration and drying in cover concrete to support the survey findings. 


\section{Field Surveys for Assessment of Corrosion and Cover Depth of Reinforced Concrete Bridges}

\subsection{Location and Inspection}

To compare the deterioration characteristics and examine the effect of cover depth on the deterioration in different Asian countries, field surveys of reinforced concrete bridges were conducted in Japan, Thailand, and Vietnam. Visual inspection was carried out to observe cracking, flaking, spalling, and rust arising from corrosion, with a focus on the boundary conditions. Corrosion was confirmed in locations where the cover concrete was spalled or dust appeared through the cracks. The cover depth was measured using a non-destructive cover meter with electromagnetic pulse induction technology, as shown in Figure 1. In the deteriorated members, the cover depth was measured at least three times within approximately $200 \mathrm{~mm}$ of the spalling or cracking. Additionally, this depth was measured at three randomly selected locations on the members without any signs of deterioration.
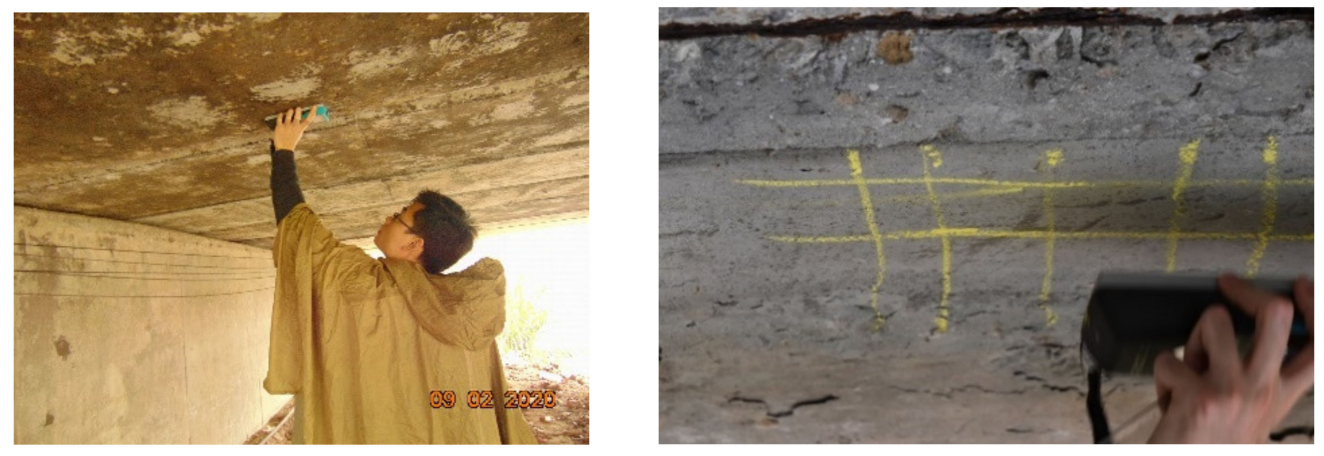

Figure 1. Cover depth measurement.

In Japan, 24 short-span bridges (2.4-14.8 m) located in Uwajima city were visually inspected in 2017, with a focus on short-slab deterioration. In Thailand, 61 bridges were randomly inspected in Bangkok, and the cover depths of 20 bridges were measured at points where physically possible. In Vietnam, 36 bridges surrounding Hanoi were inspected by measuring the cover depth. The survey areas for each country and location climate information are shown in Figure 2 and Table 1, respectively. Uwajima is located in the temperate zone to have winter with snow, while the Bangkok and Hanoi vicinities are located in the tropical and subtropical zones with frequent squalls in rainy seasons, respectively. Some bridges in the Uwajima and Hanoi vicinities can be affected by airborne chloride ions, while bridges in Bangkok far from the seashore are not attacked by chloride ions. The effect of climates and boundary conditions on the deterioration was compared.

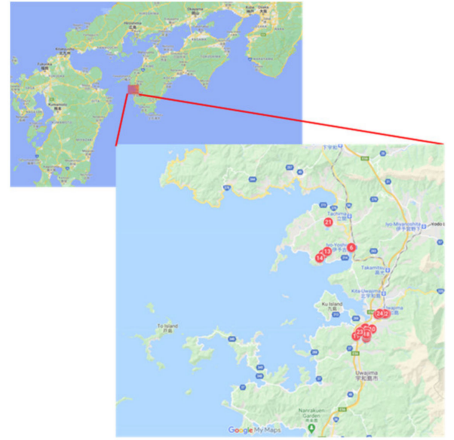

(a) Uwajima city (Japan).

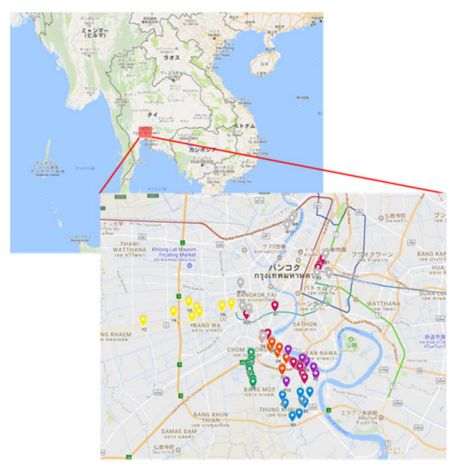

(b) Bangkok (Thailand).

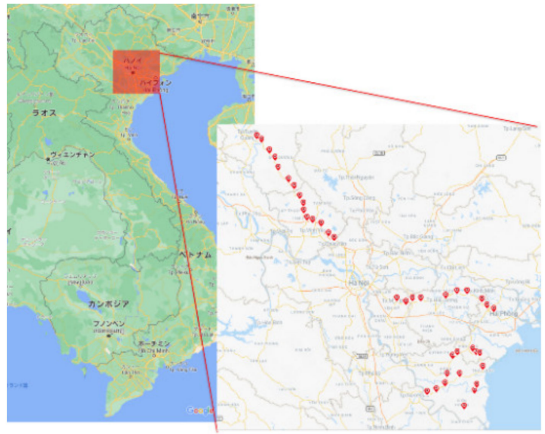

(c) Hanoi vicinities (Vietnam).

Figure 2. Survey locations in the different countries (Map data from Google 2020) (a) Uwajima city (Japan) (b) Bangkok (Thailand) (c) Hanoi vicinities (Vietnam). 
Table 1. Climate information in each location.

\begin{tabular}{|c|c|c|c|c|c|c|}
\hline & \multicolumn{3}{|c|}{ Temperature $\left({ }^{\circ} \mathrm{C}\right)$} & \multirow{2}{*}{$\begin{array}{l}\text { Average Annual } \\
\text { Humidity (\%) }\end{array}$} & \multirow{2}{*}{$\begin{array}{c}\text { Average Annual } \\
\text { Precipitation (mm) }\end{array}$} & \multirow{2}{*}{$\begin{array}{l}\text { Average Annual } \\
\text { Number of Days } \\
\text { with Precipitation }\end{array}$} \\
\hline & $\begin{array}{c}\text { Monthly } \\
\text { Average max }\end{array}$ & $\begin{array}{c}\text { Monthly } \\
\text { Average min }\end{array}$ & Annual Average & & & \\
\hline Uwajima & 32.5 & 2.5 & 17.2 & 73.8 & 1805 & 142 \\
\hline Bangkok & 34 & 21 & 28 & 73.8 & 1450 & 137 \\
\hline Hanoi & 32.2 & 15 & 23 & 85 & 1607 & 187 \\
\hline
\end{tabular}

The information in Uwajima was obtained by averaging data for five years (2012-2017) from the database of the Japan Meteorological Agency [20], while the information in Bangkok and Hanoi was obtained from the database of Canty and Associates LLC [21].

\subsection{Typical Deterioration and Relationship between Corrosion-Induced Deterioration and Cover Depth}

Typical examples of bridge deterioration owing to corrosion are shown in Figure 3. The deterioration in the slabs of the short-span bridges in Japan was mainly attributed to a small cover depth, which resulted in spalling. In Thailand and Vietnam, the ends of the girders were mostly deteriorated due to water seepage from the supply lines, and spalling in the slab similar to that in Japan was also observed. Deterioration related to water seepage is often found in Japan; however, no significant difference in the corrosion-induced deterioration was observed according to climate change.

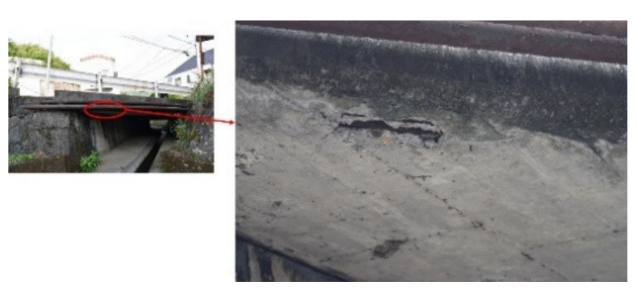

(a) Spalling in slabs in Uwajima city.
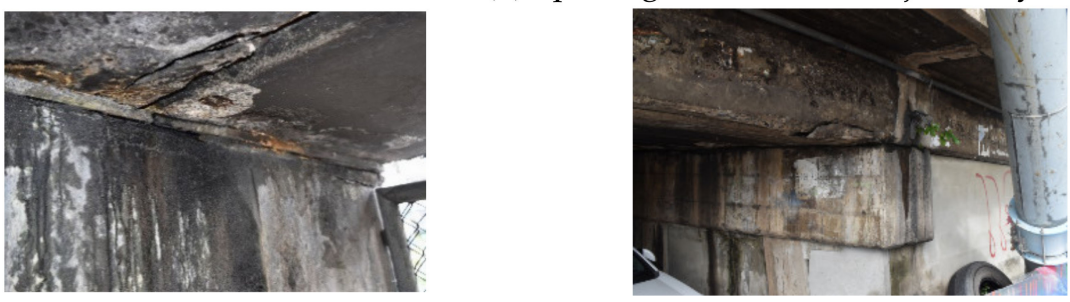
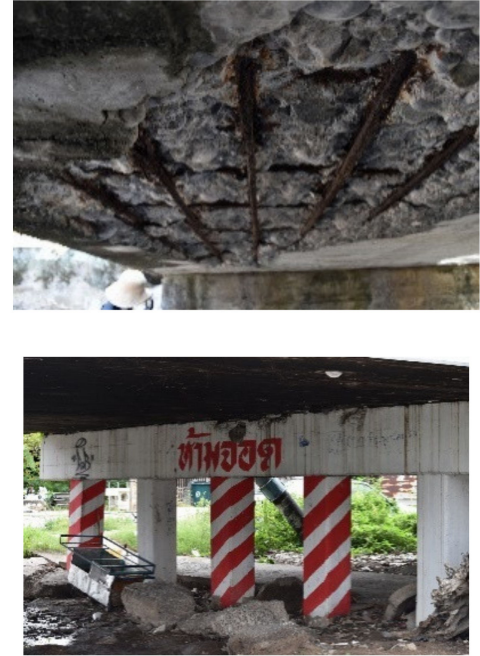

(b) Flaking and spalling at the end of the girders and at the lateral beams in Bangkok.
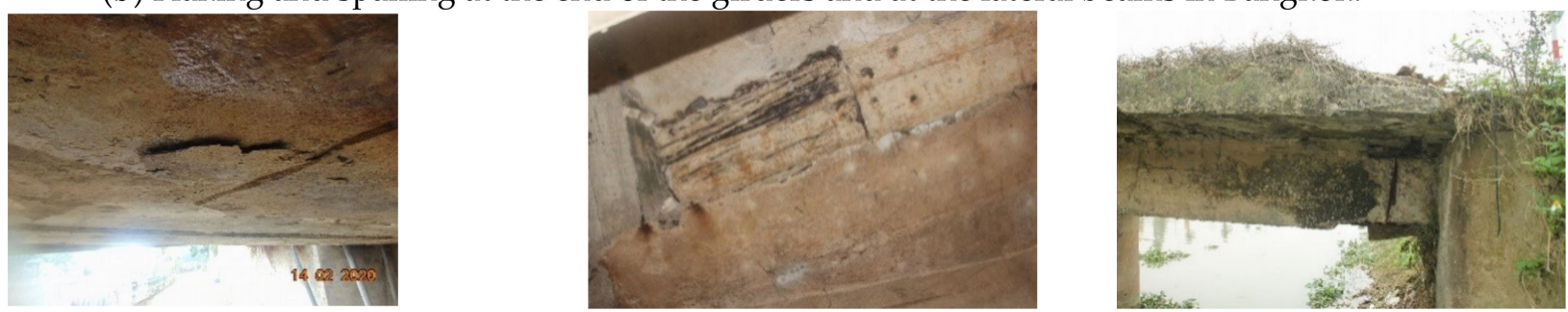

(c) Flaking and spalling in slabs and at the end of the girders near Hai-Phong city.

Figure 3. Typical examples of corrosion-induced deterioration in bridges in each selected country. (a) Spalling in slabs in Uwajima city (b) Flaking and spalling at the end of the girders and at the lateral beams in Bangkok (c) Flaking and spalling in slabs and at the end of the girders near Hai-Phong city.

The relationship between the cover depth and corrosion-induced deterioration, such as cracking or spalling, is shown in Figure 4. Regardless of the member type, a minimum cover depth of $40 \mathrm{~mm}$ prevented steel bar corrosion in Japan and Vietnam; however, a few cases of corrosion were observed in Thailand even when the cover depth was greater than $40 \mathrm{~mm}$. Figure 5 shows the relationship between the construction year and cover 
depth with or without corrosion for the bridges in Uwajima city and around Hanoi, whose construction years were obtained. The date of construction of bridges in Thailand could not be obtained. The water penetration calculation in the practical design using the LucasWashburn theory [12] reveals that moisture can infiltrate deeper into concrete with an increase in service life, eventually reaching the reinforcing steel, leading to corrosion. According to the design, corrosion should proceed to cause spalling or cracking in older structures with deeper water penetration; however, this is not observed in real structures. It is noted in this study that spalling and cracking with the observed corrosion or rust were found in some members with cover depths of less than $40 \mathrm{~mm}$, regardless of the construction year and environment in both Japan and Vietnam.

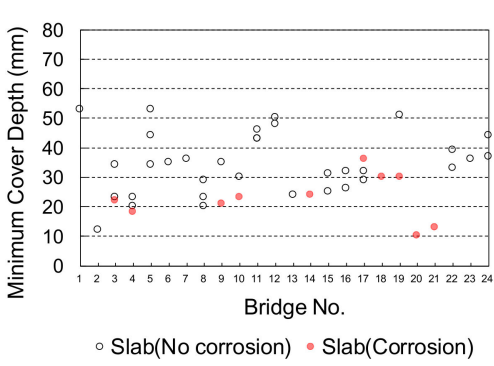

(a) Uwajima city.

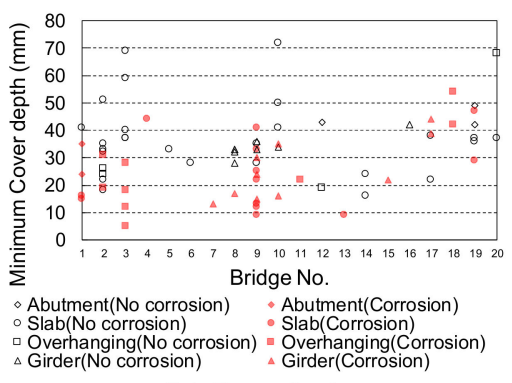

(b) Bangkok.

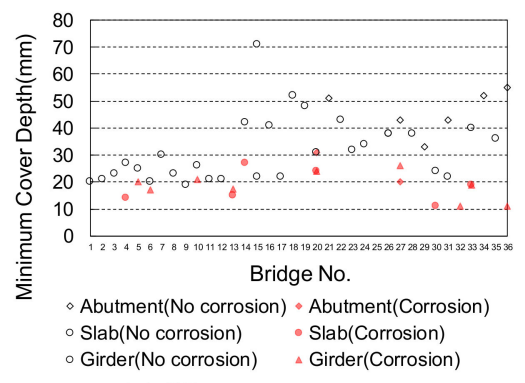

(c) Hanoi vicinities.

Figure 4. The relationship between cover depth and corrosion for bridges in each selected country. (a) Uwajima city (b) Bangkok (c) Hanoi vicinities.

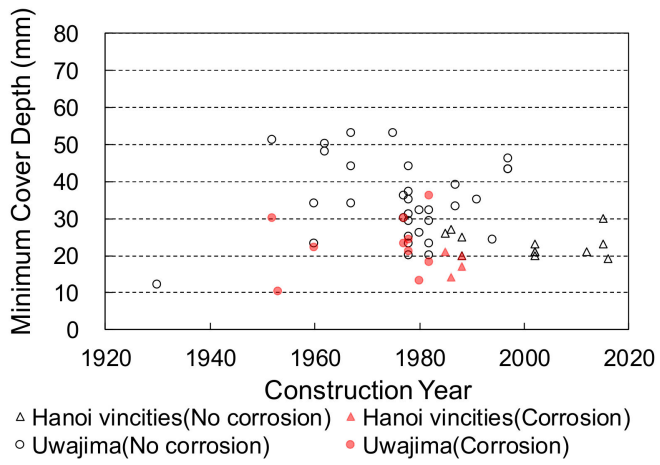

Figure 5. The relationship between construction year and minimum cover depth, with and without corrosion, in Uwajima city (Japan) and the Hanoi vicinity (Vietnam).

Based on the survey results, it is hypothesised that water penetration in real structures under drying and wetting conditions with rainfall would not exceed approximately $40 \mathrm{~mm}$ unless the cover concrete was very porous or had cracks, which were not included in our survey. Unfortunately, the survey was always carried out on sunny days because of limited time. Thus, it was impossible to clearly identify the water penetration at the measurement points during periods of rain. In addition, because the carbonation depth was also not measured owing to the difficulty in obtaining permission for coring of public bridges, a previous field survey with the detailed information is referred to in the next section to discuss the hypothesis.

\subsection{Relationship among Cover Depth, Carbonation Depth, and Spalling in Previous Field Surveys}

Similar surveys focusing on water supply and carbonation depth were reported in Japan. Ishibashi et al. [10] measured the cover depth and carbonation by drilling the cover concrete depth in 95 railway structures (mainly viaducts) with service lives ranging 15-80 years. Most of the structures were located far from the seashore. Figure 6, which 
is reproduced by the authors based on [10], shows the relationship between spalling, carbonation depth, and cover depth with and without water supplied by rainfall or other means. Spalling due to corrosion is mostly prevented when the cover depth is more than $30 \mathrm{~mm}$ regardless of the carbonation depth and age, even in the presence of water. Spalling was observed in members with a thin cover depth of less than $5 \mathrm{~mm}$, even in the absence of water.

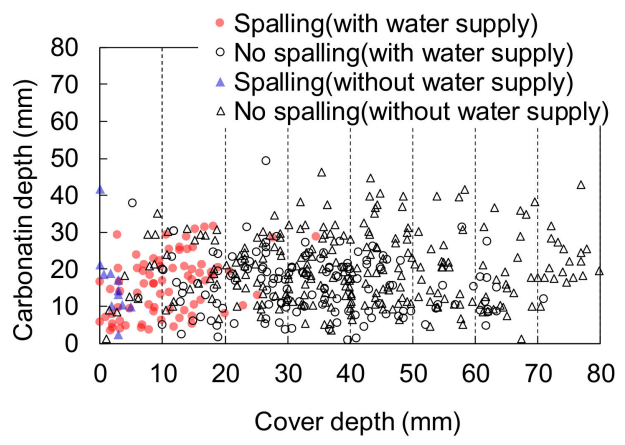

Figure 6. The relationship between carbonation depth, cover depth, and spalling, due to the corrosion with and without water supply [10] (replotted by authors).

Maehara and Iyoda [11] also surveyed cracking and spalling and measured cover depth and carbonation depth by chipping the cover concrete in 36 real structures without external chloride ion supply, such as bridges, walls, tunnels, and others in Japan. The ages ranged from 11 to 87 years at the time of the survey. Figure 7 shows the relationship between carbonation depth, cover depth, and spalling, according to the apparent corrosion level [22], which was replotted by the authors focusing on water supply. In the survey, the members with a cover depth of more than $40 \mathrm{~mm}$ had little spalling and slight corrosion, regardless of the carbonation depth, water supply and construction year, similar to the results of the survey by Ishibashi et al. [10].

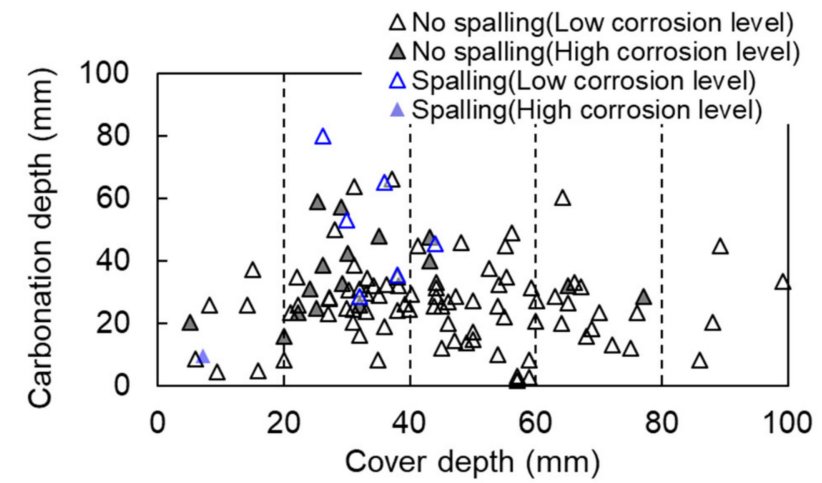

(a) Without water supply.

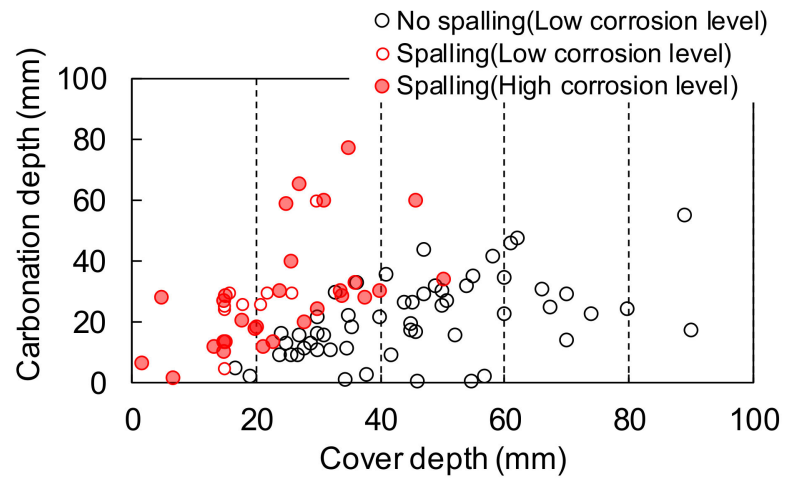

(b) With water supply.

Low corrosion level and high corrosion level were apparently evaluated to be 0 or I and IIa, Ilb, or III based on corrosion level defined by Railway Technical Research Institute [23] below;

0 : No corrosion progress after construction (Corrosion mass loss is $0 \%$ )

I: Partial surface corrosion (Corrosion mass loss is $2 \%$ )

IIa: Surface corrosion in large part (Corrosion mass loss is $4 \%$ )

IIb: Partial cross-section reduction by corrosion (Corrosion mass loss is $6 \%$ )

III: All-around cross-section reduction by corrosion (Corrosion mass loss is $10 \%$ )

Figure 7. The relationship among carbonation depth, cover depth, and spalling, according to corrosion level with and without water supply [11] (replotted by authors). (a) Without water supply (b) With water supply. 
The above surveys also suggested that an adequate cover depth of over $40 \mathrm{~mm}$ can prevent spalling by corrosion, even though porous cover concrete with a low strength of less than $15 \mathrm{MPa}$ or a high water-to-cement ratio (W/C) of over $55 \%$ was included in the surveyed structures. Carbonation in members without exposure to water can cause corrosion, although not severe enough to cause spalling. While severe corrosion causing spalling was observed mainly in members with a cover depth of less than $40 \mathrm{~mm}$ and water supply. Our survey indicated the importance of adequate cover depth to prevent spalling or cracking by steel corrosion even in the coastal areas of Uwajima city and near Hai-Phong with airborne chloride ions, which were not included in previous studies $[10,11]$. Hence, water penetration in concrete under drying and wetting conditions, which can be the most important factor causing corrosion deterioration as the specification indicates [12,13], was experimentally studied to examine the possibility of water stagnation during infiltration.

\section{Experimental Study of Moisture Penetration in Concrete under Drying and Wetting Conditions}

\subsection{Mix Proportion and Specimens}

Two types of concrete were prepared to examine the effect of $\mathrm{W} / \mathrm{C}$ on water penetration. The mix proportions are shown in Table 2, assuming dense concrete with $\mathrm{W} / \mathrm{C}=0.45$ and porous and low-strength concrete with a $\mathrm{W} / \mathrm{C}$ of 0.60 as the worst case. In the case of a lower W/C (i.e., 0.45), a chemical admixture was used to obtain the desired workability, but no admixture was used for $\mathrm{W} / \mathrm{C}=0.60$ to avoid segregation resulting from high workability.

Table 2. Mix proportion.

\begin{tabular}{|c|c|c|c|c|c|c|c|}
\hline Mix ID & W/C (\%) & $\begin{array}{c}\text { Water } \\
\left(\mathrm{kg} / \mathrm{m}^{3}\right)\end{array}$ & $\begin{array}{l}\text { Cement } \\
\left(\mathrm{kg} / \mathrm{m}^{3}\right)\end{array}$ & $\begin{array}{c}\text { Fine Aggregate } \\
\left(\mathrm{kg} / \mathrm{m}^{3}\right)\end{array}$ & $\begin{array}{l}\text { Coarse } \\
\text { Aggregate } \\
\left(\mathrm{kg} / \mathrm{m}^{3}\right)\end{array}$ & $\begin{array}{c}\text { Air-Entraining and } \\
\text { Water-Reducing Agent } \\
\left(\mathrm{mL} / \mathrm{m}^{3}\right)\end{array}$ & $\begin{array}{c}\text { Air-Entraining } \\
\text { Agent }\left(\mathrm{g} / \mathrm{m}^{3}\right)\end{array}$ \\
\hline N45 & 45 & 172 & 383 & 755 & 1003 & 958 & 23 \\
\hline N60 & 60 & 172 & 287 & 843 & 993 & - & - \\
\hline
\end{tabular}

Cement: Ordinary Portland cement $\left(\right.$ density $=3.16 \mathrm{~g} / \mathrm{cm}^{3}$ ), Fine aggregate: River sand (saturated surface dry density $\left.=2.59 \mathrm{~g} / \mathrm{cm}^{3}\right), \mathrm{Coarse}$ aggregate: Crushed gravel (maximum size $=20 \mathrm{~mm}$, saturated surface-dry density $=2.71 \mathrm{~g} / \mathrm{cm}^{3}$ ).

Concrete specimens with cover depths of 10,30, and $40 \mathrm{~mm}$, with heights of 56, 76, and $86 \mathrm{~mm}$, respectively, were cast. The heights were selected to maintain the same depth as the reinforcement. All specimens had lengths and depths of 150 and $76 \mathrm{~mm}$, respectively, with D16 steel in the centre to maintain the previously specified cover depths. To investigate the water penetration at depths of 10,30, and $40 \mathrm{~mm}$ from the surface, the electrical resistivity was measured horizontally at each depth based on the four-point (Wenner probe) method. A soft copper wire with a diameter of $1.6 \mathrm{~mm}$ was used as an electrode. The wires were inserted to a depth of approximately $20 \mathrm{~mm}$, the ends were exposed from the side of the specimens using a heat-shrinkage rubber tube after covering all other surfaces, and the interval between the electrodes was $30 \mathrm{~mm}$. Figure 8 shows a schematic representation of the specimens. 


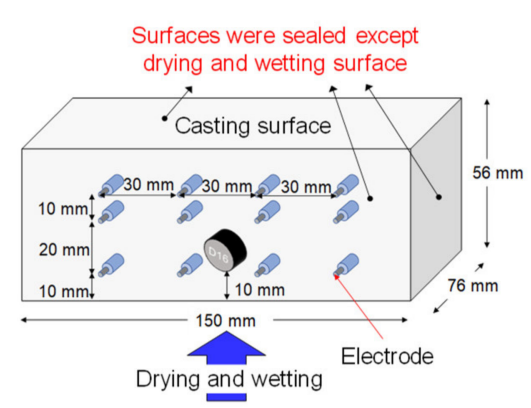

(a) Cover depth $=10 \mathrm{~mm}$.

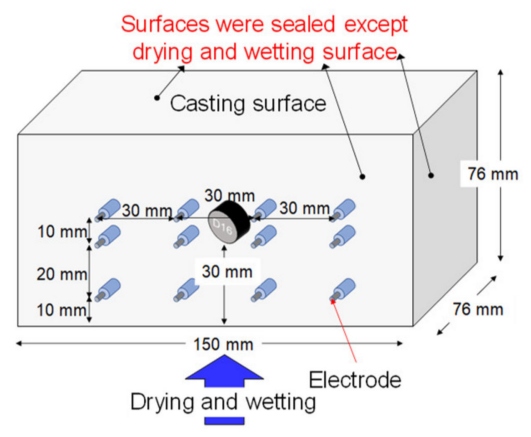

(b) Cover depth $=30 \mathrm{~mm}$.

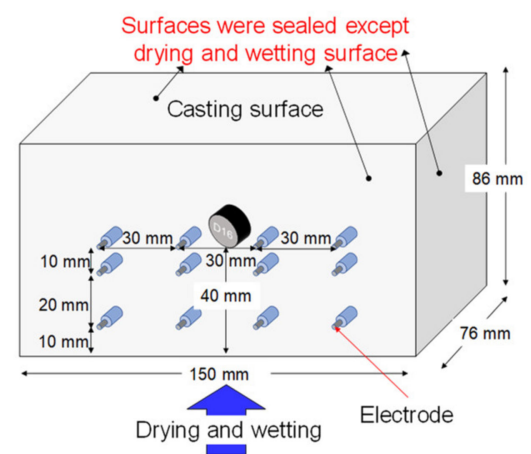

(c) Cover depth $=40 \mathrm{~mm}$.

Figure 8. A schematic representation of specimens with inserted electrodes. (a) Cover depth $=10 \mathrm{~mm}(\mathbf{b})$ Cover depth $=30 \mathrm{~mm}$ (c) Cover depth $=40 \mathrm{~mm}$.

\subsection{Experimental Program}

The specimens were cured for 4 days using sealed wooden moulds. After removing the wooden formwork, the surface opposite to the casting surface to be exposed to drying and wetting was sealed with aluminium tape, whereas the other surfaces were coated with epoxy resin to prevent moisture absorption and evaporation during the experiment. At the age of 5 days, after hardening of the resin, the aluminium tape was removed, and the bottom of the specimen without sealing was immersed in a shallow water pool with a depth of a few centimetres for 1 day, simulating wetting conditions soon after the curing. From the age of 6 days, drying was started. The specimens were dried at $40{ }^{\circ} \mathrm{C}$ under $60 \pm 2 \% \mathrm{RH}$ in the chamber, simulating the most severe drying in hot regions such as Thailand. The specimens with $\mathrm{W} / \mathrm{C}=0.6$ were also dried at $20^{\circ} \mathrm{C}$ under $60 \pm 5 \% \mathrm{RH}$ in a climate-controlled room, which is often specified in the Japan Industrial Standard as the standard drying condition for concrete [23]. After drying for 6 days, water was supplied from the bottom of the specimen as explained previously for 1 day at $20^{\circ} \mathrm{C}$ because waterinduced spalling is often found at the bottom of the member. To examine water penetration after drying, the current and voltage before and after wetting were measured to calculate the specific resistance based on the four-point method. After two cycles of drying and wetting, the specimens were dried for 13 days and then exposed to water for 3 more days to examine the effect of a longer duration of drying and wetting. The drying and wetting processes are shown in Figure 9. The weight was also measured, before and after wetting, to examine the mass loss and gain due to drying and wetting.
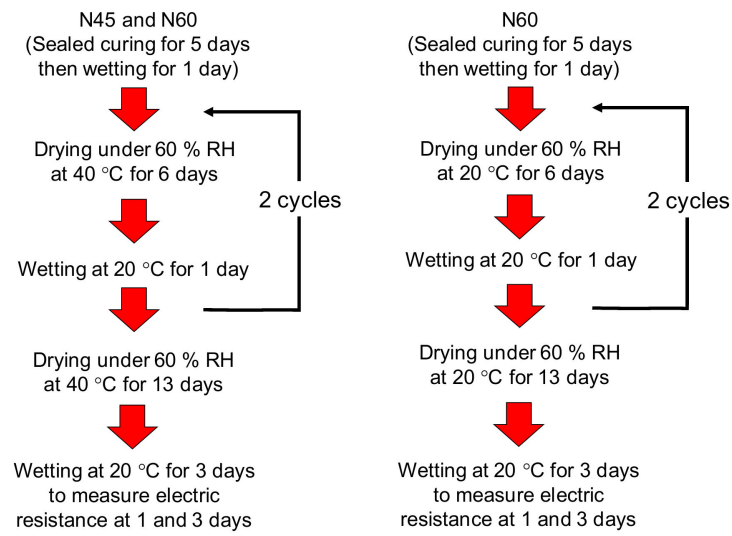

Figure 9. Summary of drying and wetting processes. 
The electrical specific resistivity was obtained to examine the water content at each depth by measuring the voltage and current in the electric wire in the specimen before and after wetting, based on the four-point (Wenner probe) method. The experiment to focus on the change in resistance due to water penetration can be utilised to discuss the one-dimensional water penetration process at each depth. An electric diagram example is shown in Figure 10. A voltage of $5 \mathrm{~V}$ and a sine wave of $100 \mathrm{~Hz}$ were used as the alternators. The specific resistance $\rho$ at each depth was calculated as follows:

$$
\rho=2 \pi a \frac{V}{I}
$$

where $a, V$, and $I$ are the distance between the electrodes, voltage, and current in the line, respectively. The current in the line was obtained by measuring the voltage at a shunt resistance of $330 \Omega$, whereas the voltage was measured between two poles at the centre. The voltages were recorded after the values were stable. The average specific resistance values of the two specimens at each depth were obtained.

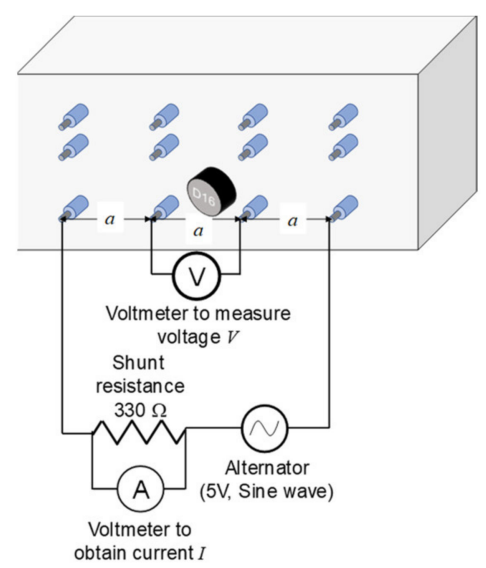

Figure 10. A schematic of the electric circuit for the specimen with a cover depth of $10 \mathrm{~mm}$.

\subsection{Results}

The change ratios of specific resistance before and after wetting for 1 day in the 1st and 2nd cycles are shown in Figure 11, as the discussion based on the change ratios can be clearer than that based on the variation in the specific resistance itself. The absolute values of specific resistance variation are presented in Appendix A. Each specimen was identified with respect to the drying conditions $\left(\mathrm{H}=40{ }^{\circ} \mathrm{C}, \mathrm{N}=20{ }^{\circ} \mathrm{C}\right)$, water-to-cement ratio $(\mathrm{W} / \mathrm{C}=45 \%$ : $\mathrm{W} 45, \mathrm{~W} / \mathrm{C}=60 \%$ : W60), and cover depth $(10 \mathrm{~mm}: \mathrm{C} 10,30 \mathrm{~mm}: \mathrm{C} 30$, $40 \mathrm{~mm}$ : C40). For instance, concrete with $\mathrm{W} / \mathrm{C}=45 \%$ and cover depth of $30 \mathrm{~mm}$ dried under an $\mathrm{RH}$ of $60 \%$ at $40{ }^{\circ} \mathrm{C}$ is termed "HW45C 30 ". The ratio of specific resistance was obtained by dividing the difference in the specific resistance before and after wetting by the specific resistance before wetting. When the water penetrates around the position of the resistance measurement, the resistance can be reduced because of the lower resistance of water, resulting in a negative change ratio before and after wetting. 

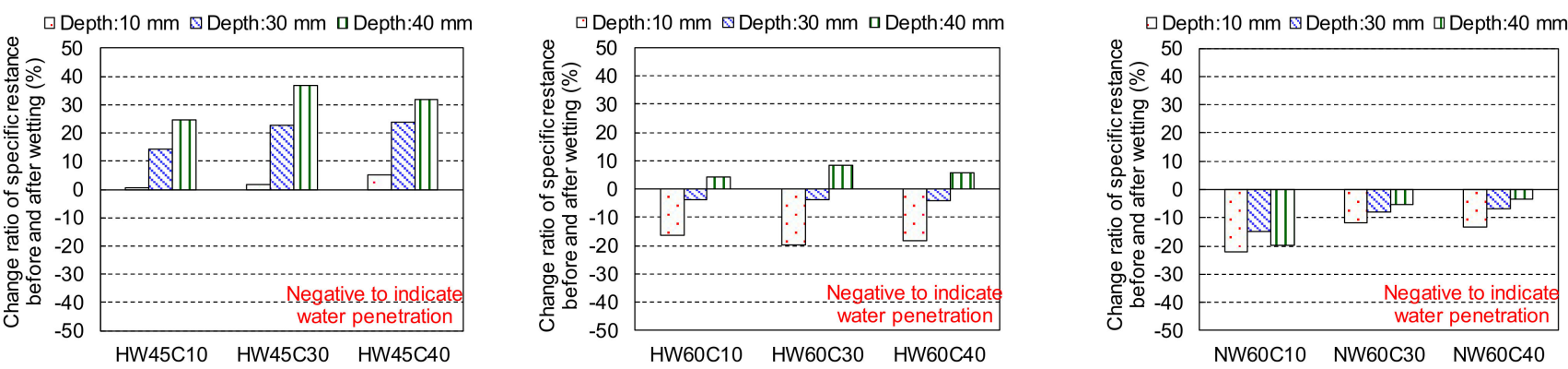

(a) Before and after wetting for 1 day in the 1 st cycle.
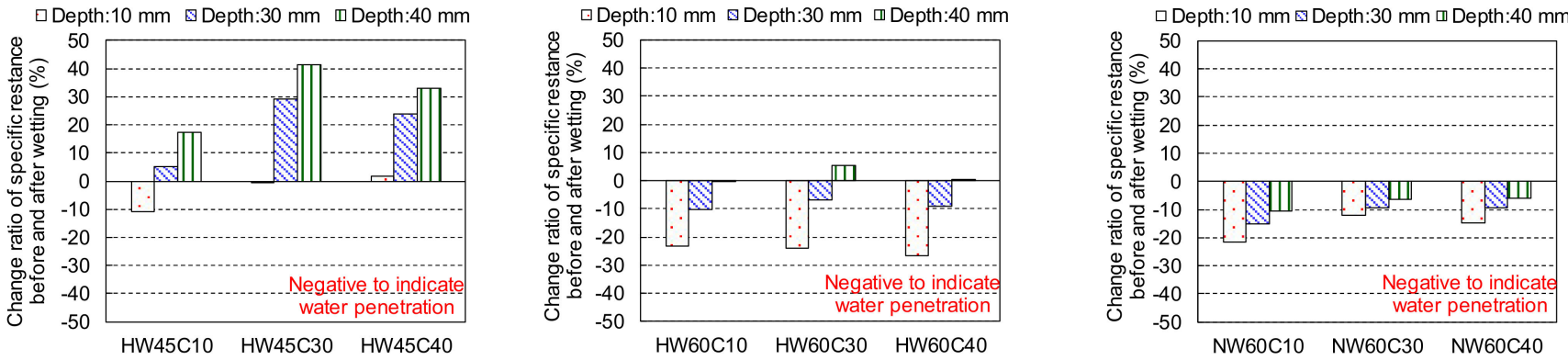

(b) Before and after wetting for 1 day in the 2 nd cycle.

Figure 11. The change ratio of specific resistance before and after wetting for 1 day after sealed curing in the 1 st and 2 nd cycles. (a) Before and after wetting for 1 day in the 1st cycle (b) Before and after wetting for 1 day in the 2 nd cycle.

In the case of low $\mathrm{W} / \mathrm{C}$, the specific resistances at various depths, except those of HW45C10 and HW45C30 at a depth of $10 \mathrm{~mm}$ in the 2nd cycle, increased even after wetting from the surface for 1 day. This could be because the progressive hydration due to the low W/C makes the pore structure denser with ageing, especially at earlier ages. This substantially prevented water penetration and consumed water in the saturated pores for hydration, even during wetting, which increased the resistance. In contrast, the specific resistances of the concrete with a $\mathrm{W} / \mathrm{C}$ of 0.6 were reduced in proportion to an increasing depth up to $30 \mathrm{~mm}$ because of the 1 day wetting after drying at $40{ }^{\circ} \mathrm{C}$. In addition, the specific resistances of the specimens dried at $20^{\circ} \mathrm{C}$ were reduced at each particular depth after 1 day of wetting which suggested the possibility of water penetration at steel. However, the resistance at depths of 30 and $40 \mathrm{~mm}$ could be reduced even by water infiltration around the dried surface at $10 \mathrm{~mm}$ under the concentric current flow around the measurement positions if the water at depths greater than $30 \mathrm{~mm}$ was not severely dried by mild drying at $20^{\circ} \mathrm{C}$ and 1 day of wetting as discussed later.

Figure 12 shows the change ratio of the specific resistance before and after wetting for 1 and 3 days in the 3rd cycle. The change in specific resistance due to wetting for 1 day, even after a longer drying period, was similar to that of the 1st and 2nd cycles after drying for 6 days, as shown in Figure 11. The resistance decreased with an increase in the wetting time in all specimens. However, the changes at 30 and $40 \mathrm{~mm}$ depths for specimens $\mathrm{HW} 45 \mathrm{C} 30$ and $\mathrm{HW} 45 \mathrm{C} 40$ with low $\mathrm{W} / \mathrm{C}$ were still positive even after wetting for 3 days, indicating that no water infiltration occurred until a depth of $30 \mathrm{~mm}$ due to the dense pore structures and the effects of self-desiccation. In the specimens with $\mathrm{W} / \mathrm{C}=60 \%$, the resistance reduction ratios from 1 day to 3 days in the wetting process were larger at depths of 30 and $40 \mathrm{~mm}$ when dried at $40{ }^{\circ} \mathrm{C}$, than when dried at $20^{\circ} \mathrm{C}$. This suggested that the water gradually penetrated deeper through unsaturated pores with an increase in the wetting period after drying at higher temperatures, whereas the water could not penetrate in less unsaturated pores, indicating a slight effect of a long wetting period on the resistance reduction when dried for 13 days at $20^{\circ} \mathrm{C}$. 
$\square$ Depth:10 mm (1 day wetting) \& Depth:30 mm (1 day wetting) םDepth:40 mm (1 day wetting) ๑Depth:10 mm ( 3 days wetting) $₫$ Depth: $30 \mathrm{~mm}$ ( 3 days wetting) $\boxminus$ Depth:40 mm ( 3 days wetting)

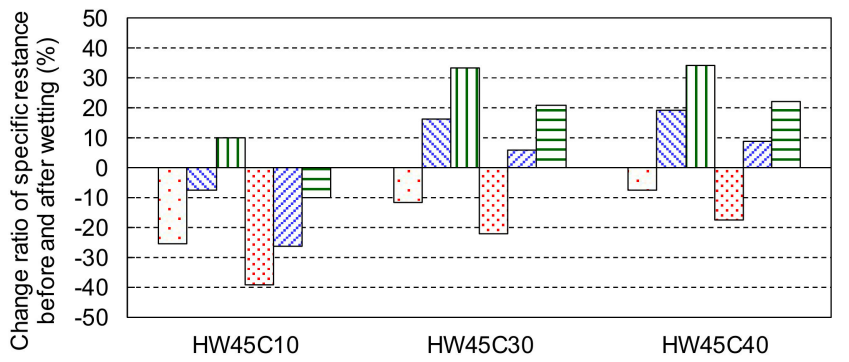

(a) Specimens with $\mathrm{W} / \mathrm{C}=45 \%$ dried under $\mathrm{RH}=60 \%$ at $40{ }^{\circ} \mathrm{C}$.

$\square$ Depth:10 mm (1 day wetting) @ Depth:30 mm (1 day wetting) ®Depth:40 mm (1 day wetting) ๒Depth: $10 \mathrm{~mm}$ ( 3 days wetting) $\approx$ Depth: $30 \mathrm{~mm}$ ( 3 days wetting) $\boxminus$ Depth: $40 \mathrm{~mm}$ ( 3 days wetting)

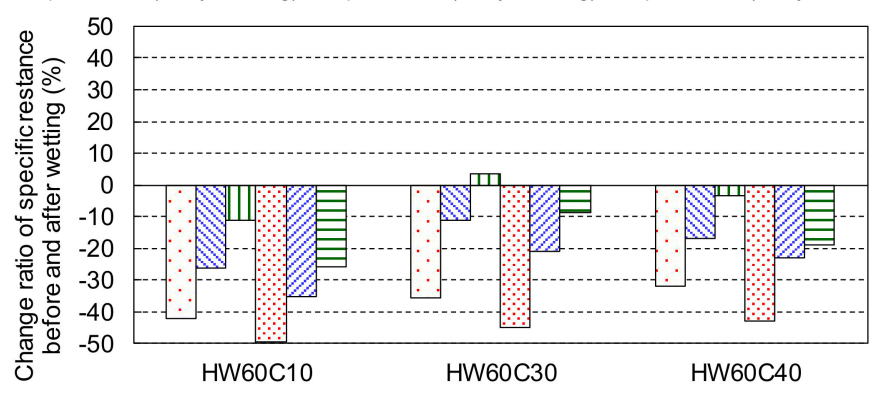

(b) Specimens with $\mathrm{W} / \mathrm{C}=60 \%$ dried under $\mathrm{RH}=60 \%$ at $40{ }^{\circ} \mathrm{C}$.

$\square$ Depth:10 mm (1 day wetting) @Depth:30 mm (1 day wetting) \Depth:40 mm (1 day wetting)

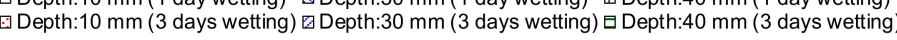

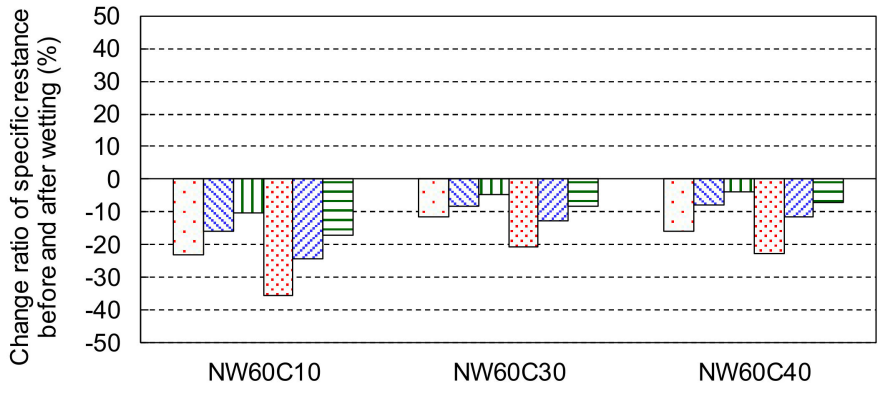

(c) Specimens with $\mathrm{W} / \mathrm{C}=60 \%$ dried under $\mathrm{RH}=60 \%$ at $20{ }^{\circ} \mathrm{C}$.

Figure 12. The change ratio of specific resistance before and after wetting for 1 and 3 days on the 3rd cycle. (a) Specimens with $\mathrm{W} / \mathrm{C}=45 \%$ dried under $\mathrm{RH}=60 \%$ at $40{ }^{\circ} \mathrm{C}$ (b) Specimens with $\mathrm{W} / \mathrm{C}=60 \%$ dried under $\mathrm{RH}=60 \%$ at $40{ }^{\circ} \mathrm{C}$ (c) Specimens with $\mathrm{W} / \mathrm{C}=60 \%$ dried under $\mathrm{RH}=60 \%$ at $20{ }^{\circ} \mathrm{C}$.

\subsection{Discussion}

According to the change ratios of specific resistance at various depths of specimens before and after wetting for 1 and 3 days, it is suggested that the water does not reach the steel position at a depth of $40 \mathrm{~mm}$ in concrete with $\mathrm{W} / \mathrm{C}=45 \%$ after drying at $40{ }^{\circ} \mathrm{C}$. In the case of higher $\mathrm{W} / \mathrm{C}=60 \%$, the water may penetrate at a depth of $40 \mathrm{~mm}$ through unsaturated pores with an increase in the wetting period, especially after severe drying at $40{ }^{\circ} \mathrm{C}$, but it is plausible that the water penetration at a deeper depth over $30 \mathrm{~mm}$ might be inhibited through less unsaturated pores after less severe drying at $\mathrm{RH}=60 \%$ at $20^{\circ} \mathrm{C}$.

To explicitly examine the water penetration at each depth, the specimens after the 3rd cycle were dried again under the same drying conditions for 6 days, and the mass loss due to oven drying at $105^{\circ} \mathrm{C}$ was measured at each depth before and after wetting for 3 days. One side of the specimens with a cover depth of $40 \mathrm{~mm}$ was sliced with a cut approximately $20 \mathrm{~mm}$ thick and perpendicular to the drying and wetting surface using a 
concrete cutter. Subsequently, the sliced samples were cut at $20 \mathrm{~mm}$ intervals from the top and dried at $105^{\circ} \mathrm{C}$ to measure the moisture content at each depth.

Figure 13 shows the moisture content measurement results. The moisture of the specimen with a W/C of $45 \%$ did not increase at depths of 20-40 and 40-60 mm after wetting for 3 days; whereas, an increase in the moisture content of specimens with $0-20 \mathrm{~mm}$ depth was observed due to water penetration, as indicated by the electric resistance. This was attributed to the dense pore structure, which requires a longer time for water to penetrate deeply. In contrast, in specimens HW60C40, the moisture content at any depth increased markedly, indicating that water penetrated to an approximate depth of $40 \mathrm{~mm}$ from the surface by wetting for 3 days after drying at $40{ }^{\circ} \mathrm{C}$. Concrete with $\mathrm{W} / \mathrm{C}=60 \%$ has coarser pore structures, which could allow water migration largely owing to the capillary suction when dried, resulting in an increased moisture content up to $40-60 \mathrm{~mm}$ after 3 days of wetting. However, the water did not reach depths of approximately $40 \mathrm{~mm}$ in only 1 day of wetting after drying at $40^{\circ} \mathrm{C}$ for 6 days because the electric resistance did not decrease before and after 1-day wetting, except in the case of HW60C10, as shown in Figure 11. When the concrete was dried at $\mathrm{RH}=60 \%$ at $20^{\circ} \mathrm{C}$ for 6 days, the moisture content before wetting at depths of 20-40 and 40-60 mm did not differ, indicating that the pores at depths greater than $20 \mathrm{~mm}$ would not be dried under mild drying conditions for 6 days. Even when water was introduced from the surface after drying, the moisture content at depths greater than $20 \mathrm{~mm}$ did not change because the water could not infiltrate deeper through the saturated pores, whereas the electric resistance was reduced after wetting, as shown in Figure 11.

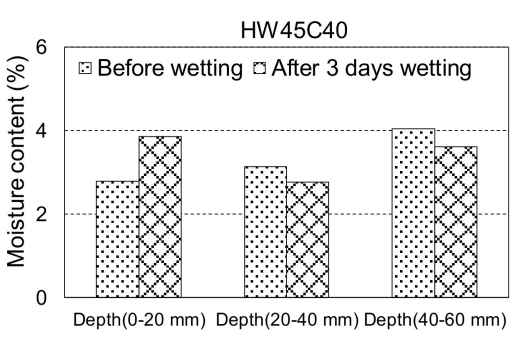

(a) Specimens with $\mathrm{W} / \mathrm{C}=45 \%$ dried under $\mathrm{RH}=60 \%$ at $40{ }^{\circ} \mathrm{C}$.

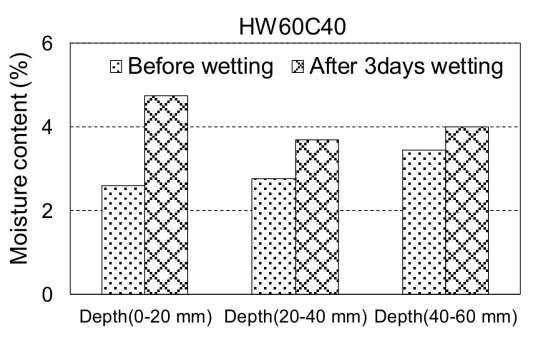

(b) Specimens with $\mathrm{W} / \mathrm{C}=60 \%$ dried under $\mathrm{RH}=60 \%$ at $40{ }^{\circ} \mathrm{C}$.

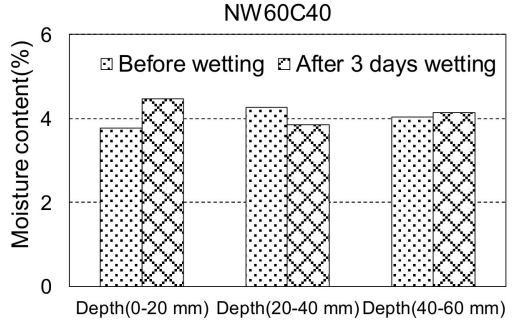

(c) Specimens with $\mathrm{W} / \mathrm{C}=60 \%$ dried under $\mathrm{RH}=60 \%$ at $20^{\circ} \mathrm{C}$.

Figure 13. The moisture content at each depth before and after 3 days wetting for the 3rd cycle. (a) Specimens with $\mathrm{W} / \mathrm{C}=45 \%$ dried under $\mathrm{RH}=60 \%$ at $40{ }^{\circ} \mathrm{C}\left(\right.$ b) Specimens with $\mathrm{W} / \mathrm{C}=60 \%$ dried under $\mathrm{RH}=60 \%$ at $40{ }^{\circ} \mathrm{C}$ (c) Specimens with $\mathrm{W} / \mathrm{C}=60 \%$ dried under $\mathrm{RH}=60 \%$ at $20{ }^{\circ} \mathrm{C}$.

As assumed previously, the resistance of the NW60 specimens at depths of 20 and $40 \mathrm{~mm}$ would be influenced by water penetration into the surface to approximately $20 \mathrm{~mm}$, even though the moisture content did not change at further depths. This implied that mild drying at $20^{\circ} \mathrm{C}$ might take a longer time to remove water from the pores deeper than $20 \mathrm{~mm}$ and permits water infiltration only near the surface with less unsaturated pores.

As shown in Figures 11 and 12, the smaller cover depth exhibited a higher resistance reduction at any depth after wetting, which indicates more and deeper water penetration. Figure 14 shows the change in mass after drying for $6 \mathrm{~d}$. The specimens with smaller cover depths lost more water during drying. Although the specimens of HW60C10 dried at $40{ }^{\circ} \mathrm{C}$ had a slight change in mass compared to HW60C 30 and HW60C40, which have larger cover depths, the result may contain some errors because the mass change due to drying was smaller than that of $\mathrm{HW} 45 \mathrm{C} 10$ with the same dimensions, which have denser pore structures. Eddy et al. [24] reported that the pore structure becomes coarse with a thinner concrete cover. These results can be attributed to a coarser pore structure, which has a smaller resistance to water infiltration and more moisture loss during drying. Hence, 
concrete with a smaller cover depth allows more water penetration owing to the coarser pore structures.

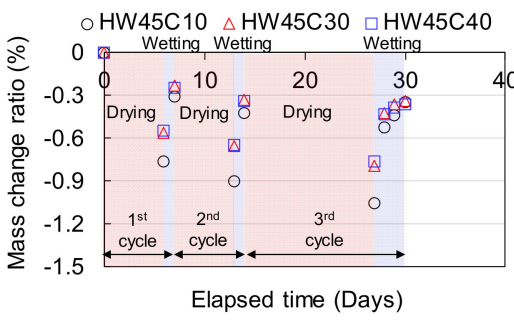

(a) Specimens with $\mathrm{W} / \mathrm{C}=45 \%$ dried under $\mathrm{RH}=60 \%$ at $40{ }^{\circ} \mathrm{C}$.

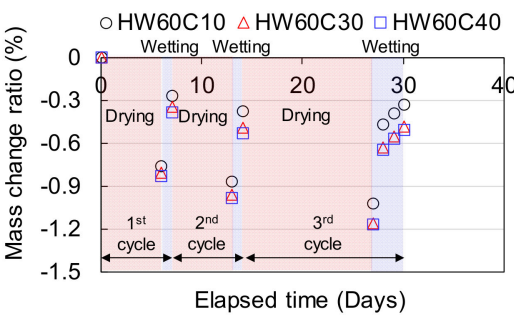

(b) Specimens with $\mathrm{W} / \mathrm{C}=60 \%$ dried under $\mathrm{RH}=60 \%$ at $40{ }^{\circ} \mathrm{C}$.

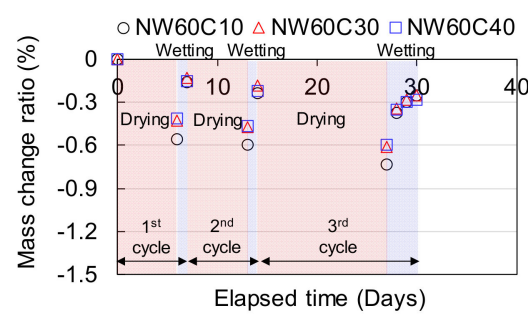

(c) Specimens with $\mathrm{W} / \mathrm{C}=60 \%$ dried under $\mathrm{RH}=60 \%$ at $20^{\circ} \mathrm{C}$.

Figure 14. Mass loss after drying at the age of 6 days. (a) Specimens with $\mathrm{W} / \mathrm{C}=45 \%$ dried under $\mathrm{RH}=60 \%$ at $40{ }^{\circ} \mathrm{C}(\mathbf{b})$ Specimens with $\mathrm{W} / \mathrm{C}=60 \%$ dried under $\mathrm{RH}=60 \%$ at $40{ }^{\circ} \mathrm{C}$ (c) Specimens with $\mathrm{W} / \mathrm{C}=60 \%$ dried under $\mathrm{RH}=60 \%$ at $20{ }^{\circ} \mathrm{C}$.

The experiment to study the water penetration under wetting and drying conditions revealed that the water penetration at a depth of $40 \mathrm{~mm}$ could be inhibited, especially in the concrete with lower $\mathrm{W} / \mathrm{C}$ and larger cover depth and the penetration depth by wetting is dependent on the pore saturation after drying. Hence, the numerical analysis was carried out to investigate the internal moisture states in pores according to drying conditions and period.

\section{Discussion of Experimental Results Using Numerical Analysis of Drying Process}

To quantitatively investigate the internal moisture states in pores during the drying process in the above experiment, the variations in pore humidity and the saturation of pores, such as capillary and gel pores, due to drying under $\mathrm{RH}=60 \%$ at 20 and $40{ }^{\circ} \mathrm{C}$ were numerically calculated. The thermodynamic simulator for concrete, named DuCOM (Durability of Concrete Model, Ver. 5.112007 model, Tokyo), developed by the University of Tokyo was used. DuCOM consists of multicomponent hydration, a micropore development structure, and a moisture equilibrium/transport model [25,26].

The calculated pore distribution of the tested concrete after 5 days of sealed curing is shown in Figure 15. Concrete with $\mathrm{W} / \mathrm{C}=45 \%$ has a denser pore structure than concrete with $\mathrm{W} / \mathrm{C}=60 \%$, especially for pore radii above $100 \mathrm{~nm}$, which comprises mainly capillary pores. This is because more hydrates precipitated in concrete capillary pores with lower $\mathrm{W} / \mathrm{C}$, according to the definition of capillary pores in DuCOM [27].

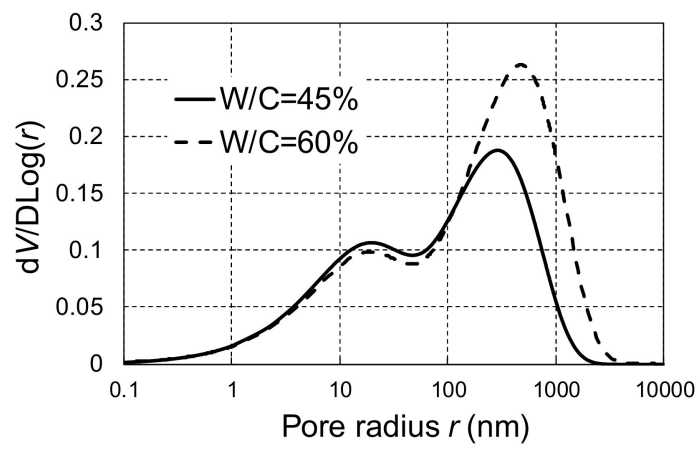

Figure 15. Pore distribution of concrete after sealed curing.

DuCOM can determine the internal moisture states of concrete with any mix proportion and size under various drying conditions, including high temperatures [28]. The simulation focused on the moisture states from the dried surface along with the depth for 
different drying times and temperatures because a detailed discussion of water penetration into unsaturated pores by drying requires a consistent experiment. Additionally, model verification is not possible because of limited experimental results. Hence, the drying process after sealed curing for 5 days and wetting for 1 day with a simple assumption of a boundary $\mathrm{RH}=99.5 \%$ at the wetting surface was analysed from the start of drying to 30 days of drying without wetting using water.

The variations in internal pore humidity, total water content with physically evaporable water and chemically bound water, and degree of saturation in the capillary and gel pores defined by DuCOM due to drying under $\mathrm{RH}=60 \%$ at 20 and $40{ }^{\circ} \mathrm{C}$ are shown in Figure 16. The pore humidity and water content were gradually reduced from the drying surface with increasing drying time; however, they decreased insignificantly at depths greater than $40 \mathrm{~mm}$ even after 13 days of drying. The humidity and water content reduction by drying was more significant at higher temperatures for both types of concrete. The gradual reduction in the pore humidity in the concrete with $\mathrm{W} / \mathrm{C}=45 \%$ is also attributed to the consumption of water for hydration (self-desiccation) even at depths greater than $40 \mathrm{~mm}$. The total water content with chemically bound water was almost the same at depths of over $20 \mathrm{~mm}$ after drying for 6 days at $20^{\circ} \mathrm{C}$, while the water content was reduced at depths of 20-30 mm after drying for 6 days at $40{ }^{\circ} \mathrm{C}$, especially in the case of $\mathrm{W} / \mathrm{C}=60 \%$. The calculated results are comparable to the measured moisture contents, as shown in Figure 13, which indicates no difference at depths of 20-40 and 40-60 mm after drying for 6 days at $20^{\circ} \mathrm{C}$ and an increase in moisture content along with the depth after drying at $40{ }^{\circ} \mathrm{C}$. The degree of saturation in the capillary pores also gradually decreased from the surface with drying, whereas that in the gel pores was reduced only around the drying surface, and it was maximum at a depth of $15 \mathrm{~mm}$ in the case of $\mathrm{W} / \mathrm{C}=45 \%$. The capillary pores can be slightly desiccated along with a depth of more than $30 \mathrm{~mm}$ when dried for 13 days at $40{ }^{\circ} \mathrm{C}$, whereas the degree of saturation remains almost the same along with the depth for over $20 \mathrm{~mm}$ in the case of concrete with $\mathrm{W} / \mathrm{C}=60 \%$ dried at $20^{\circ} \mathrm{C}$. Although the capillary pores at depths beyond $30 \mathrm{~mm}$ are partially dried when exposed to $40{ }^{\circ} \mathrm{C}$ for 13 days, as indicated by the simulation, it is assumed that it would be difficult for water from the wetting surface to penetrate to a depth of more than $30 \mathrm{~mm}$ in the lower W/C concrete with fewer capillary pores, as shown in Figure 15.

When drying was carried out for 30 days at $40{ }^{\circ} \mathrm{C}$ in the simulation, the pore humidity, total water content, and degree of saturation in the capillary pores at depths exceeding $40 \mathrm{~mm}$ can be decreased; however, at a depth exceeding $50 \mathrm{~mm}$, the reduction is attributed to self-desiccation. After drying at $20^{\circ} \mathrm{C}$ for 30 days, the moisture evaporated at a depth of less than $30 \mathrm{~mm}$. Based on the numerical analysis for the drying of concrete with $\mathrm{W} / \mathrm{C}=0.45$ and 0.60 , it was concluded that maximum moisture evaporation in conventional concrete occurred at a depth of approximately $30-40 \mathrm{~mm}$, especially in relatively large pores such as capillary pores, unless the concrete was exposed to continuous drying for more than one month. The oxygen, which is also necessary for corrosion, can easily penetrate into cover concrete through the unsaturated pores but may be difficult to diffuse at deeper depth over $40 \mathrm{~mm}$ where would keep high pore humidity over $90 \%$ according to the simulation. 

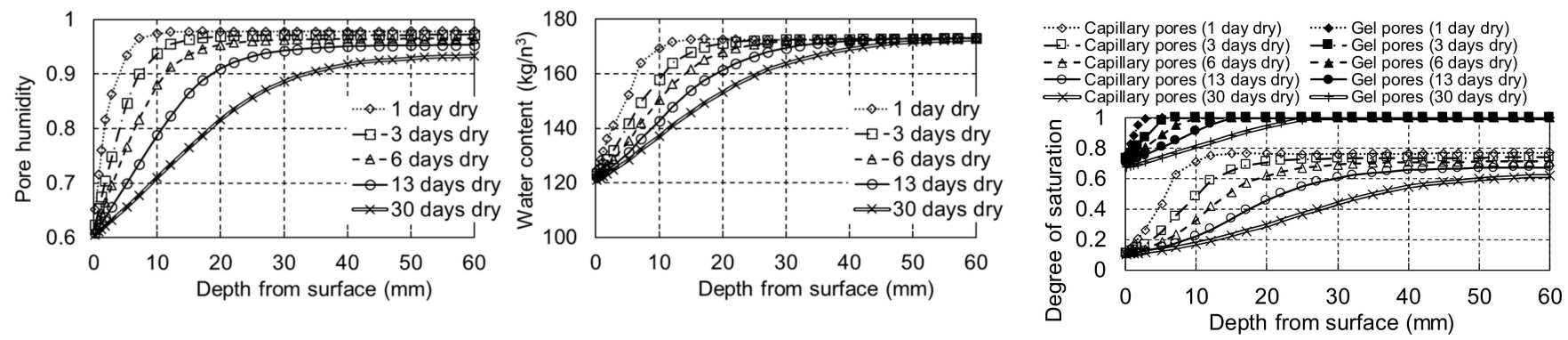

(a) Specimens with $\mathrm{W} / \mathrm{C}=45 \%$ dried under $\mathrm{RH}=60 \%$ at $40{ }^{\circ} \mathrm{C}$.
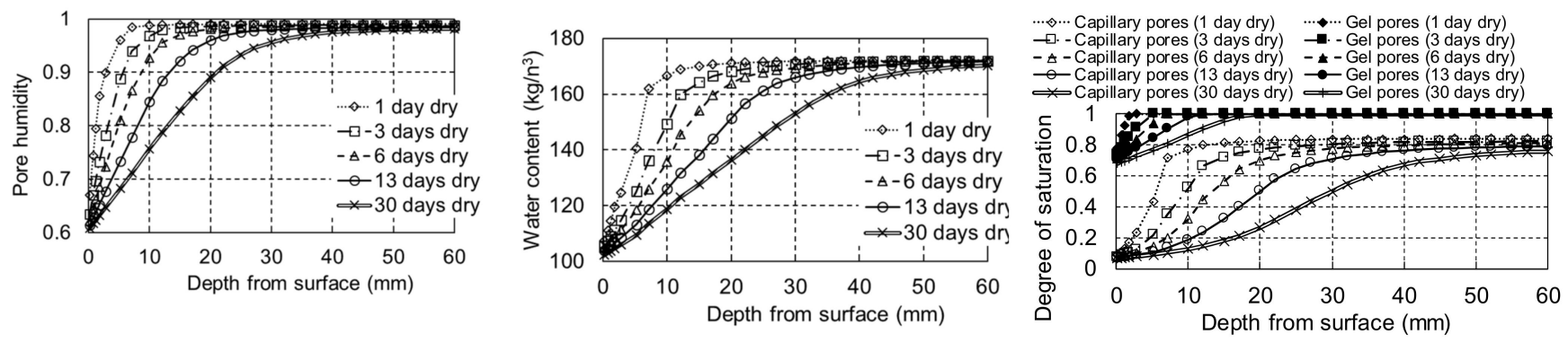

(b) Specimens with $\mathrm{W} / \mathrm{C}=60 \%$ dried under $\mathrm{RH}=60 \%$ at $40{ }^{\circ} \mathrm{C}$.
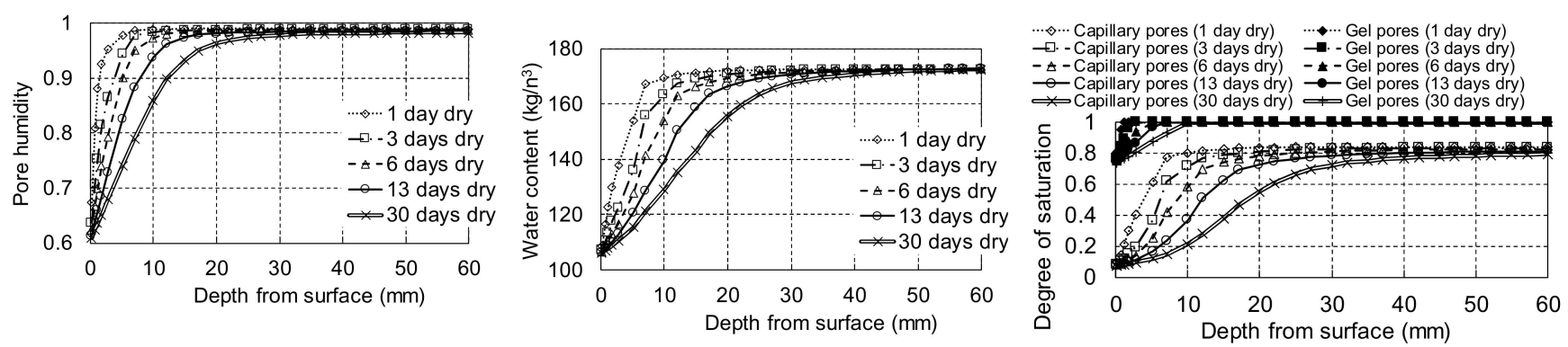

(c) Specimens with $\mathrm{W} / \mathrm{C}=60 \%$ dried under $\mathrm{RH}=60 \%$ at $20^{\circ} \mathrm{C}$.

Figure 16. Calculated variation in pore humidity, water content, and degree of saturation with drying in each specimen using DuCOM. (a) Specimens with $\mathrm{W} / \mathrm{C}=45 \%$ dried under $\mathrm{RH}=60 \%$ at $40{ }^{\circ} \mathrm{C}$ (b) Specimens with $\mathrm{W} / \mathrm{C}=60 \%$ dried under $\mathrm{RH}=60 \%$ at $40{ }^{\circ} \mathrm{C}(\mathrm{c})$ Specimens with $\mathrm{W} / \mathrm{C}=60 \%$ dried under $\mathrm{RH}=60 \%$ at $20{ }^{\circ} \mathrm{C}$.

Laboratory experiments indicated that it is difficult for water to infiltrate through dense pore structures or few unsaturated pores to a depth exceeding $40 \mathrm{~mm}$. Drying of concrete is inhibited by natural periodic rainfall, as reported in a previous study [29]. The numerical simulation indicated that a significantly longer time was required to dry relatively large capillary pores at depths of more than $40 \mathrm{~mm}$, even when dried for one month under $\mathrm{RH}=60 \%$ at $40{ }^{\circ} \mathrm{C}$. Although the pores several centimetres deep became partially unsaturated under severe drying, such as at an elevated temperature of $40{ }^{\circ} \mathrm{C}$, the wetting duration of a few days of rainfall may not be sufficient for water to penetrate the reinforcement with a cover depth of approximately $40 \mathrm{~mm}$, as suggested in the described experiment. It is also indicated that the surface region of concrete exposed to water is not instantaneously saturated, and the water uptake slows with an increase in moisture content [30]. It would support the survey findings that the members with a cover depth of more than $40 \mathrm{~mm}$ were unlikely to have the corrosion-induced spalling in Thailand with high ambient temperature all seasons and frequent squall. Additionally, the experimental and numerical studies suggested that the mild drying condition with $\mathrm{RH}=60 \%$ at $20{ }^{\circ} \mathrm{C}$ corresponding to the approximate average $\mathrm{RH}$ and temperature in Japan and Vietnam cannot cause severe drying in pores of the cover concrete at depths of greater than $40 \mathrm{~mm}$ 
when the water is frequently supplied. A high degree of saturation in the cover concrete can prevent oxygen penetration through unsaturated pores, which inhibits corrosion.

In conclusion, it is difficult for both water and oxygen to not infiltrate the reinforcing steel of concrete with adequate cover depth, such as $40 \mathrm{~mm}$, and to cause severe corrosion, as indicated in the field survey in Japan, Vietnam and Thailand with different climates. Li et al. [31] numerically investigated the influential depth of moisture transport in concrete under drying-wetting conditions and suggested an adequate depth of approximately $30 \mathrm{~mm}$, which is reasonably consistent with our study. A more consistent and quantitative discussion based on both numerical and experimental approaches is necessary to determine the effective cover depth to inhibit corrosion caused by water penetration as well as oxygen diffusion. The preliminary results of this study emphasised the importance of an adequate concrete cover depth for the prevention of deterioration due to corrosion based on both on-site and laboratory investigations.

\section{Conclusion}

In this study, the corrosion-induced deterioration of reinforced concrete bridges in Japan, Thailand, and Vietnam was visually surveyed, and the cover depth in the members around the deterioration was measured and compared to those without deterioration. In addition, the water infiltration in specimens with different cover depths under drying and wetting cycles was examined to measure the specific electric resistance. The findings and suggestions of this study are summarised as follows:

(1) Corrosion-induced deterioration in bridges was frequently observed where water was continuously supplied from rainfall and other means, regardless of climatic region and member type.

(2) Reinforced concrete members with cover depths exceeding $40 \mathrm{~mm}$, except in a few cases, were protected from visible spalling by corrosion in all surveyed countries, regardless of the boundary conditions and construction year.

(3) It was experimentally found that water penetration, owing to wetting for a few days after drying for approximately 1 or 2 weeks, cannot exceed $40 \mathrm{~mm}$ in the case of $\mathrm{W} / \mathrm{C}=45 \%$ and mild drying at $20^{\circ} \mathrm{C}$.

(4) The numerical simulation indicated that significant time ( $>1$ month) was required to dry relatively large capillary pores at depths of more than $40 \mathrm{~mm}$. It is suggested that the capillary pores in the cover concrete with a depth of over $40 \mathrm{~mm}$ may be mostly saturated owing to the natural periodic rainfall, leading to the difficulty of water and oxygen penetration into the reinforcement to cause corrosion, despite an increase in service life as indicated in the field survey.

Author Contributions: Conceptualization, S.A. and S.O.; methodology, S.A. and S.O.; software, S.A.; investigation, J.S., R.S., and G.H.N.; data curation, J.S.; writing—original draft preparation, S.A.; writing - review and editing, S.O.; visualization, S.A. and J.S.; supervision, S.A.; project administration, S.A., S.O., P.-j.C., R.S., and G.H.N.; funding acquisition, S.A. and P.-j.C. All authors have read and agreed to the published version of the manuscript.

Funding: This study was financially supported by the Cross-Ministerial Strategic Innovation Promotion Program (SIP), JSPS Core-to-Core Program B. Asia-Africa Science Platforms, and JSCE Research Promotion for International Deployment of Infrastructure Management Technology.

Institutional Review Board Statement: Not applicable.

Informed Consent Statement: Not applicable.

Data Availability Statement: The data is contained within the article.

Acknowledgments: The authors appreciate the help provided by Nguyen Trung Kien and Phan Ngoc Hiep for completing the survey in Vietnam and are thankful to Tetsuya Ishida (University of Tokyo) for kindly allowing us to use DuCOM. We also appreciate Isao Kurashige (Central Research Institute of Electric Power Industry) for his helpful comments on the survey.

Conflicts of Interest: The authors declare no conflict of interest. 


\section{Appendix A}

The variation in the specific resistance of each specimen at each measured depth is shown in Figure A1. Resistance is generally higher at a depth of $10 \mathrm{~mm}$ owing to more unsaturated pores by drying than at depths of 30 and $40 \mathrm{~mm}$. The electrons can flow significantly through more saturated pores in the concrete dried at $20^{\circ} \mathrm{C}$ (NW60 series) to make the resistances lower than those of concrete dried at $40{ }^{\circ} \mathrm{C}$ (HW60 series). In the case of concrete with an adequate cover depth of $40 \mathrm{~mm}$, the increase in the difference between depths of 30 and $40 \mathrm{~mm}$ increased with longer drying at $40^{\circ} \mathrm{C}$, while the difference was not found under drying at $20^{\circ} \mathrm{C}$. The change in resistivity may be dependent on the saturation of the capillary pores, as numerically suggested in Figure 16.

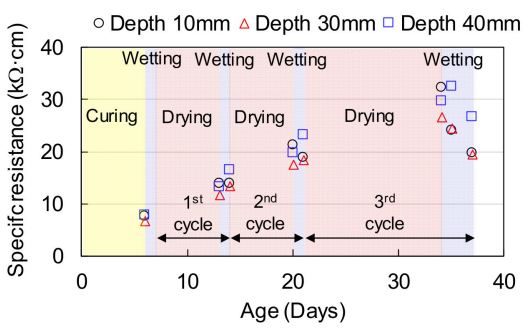

HW45C10

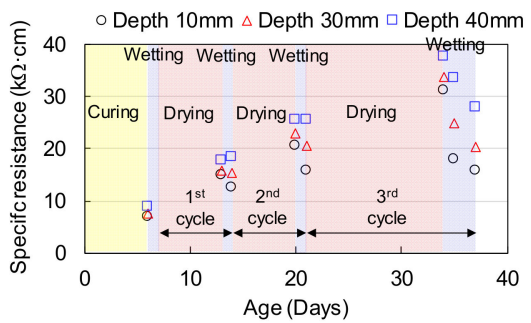

HW60C10

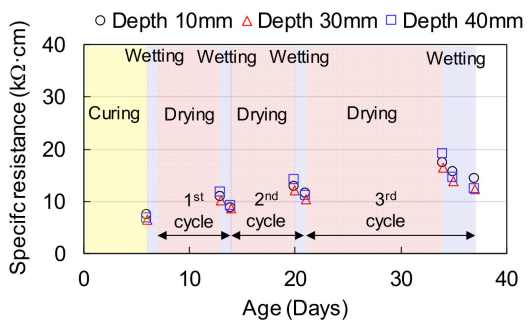

NW60C10

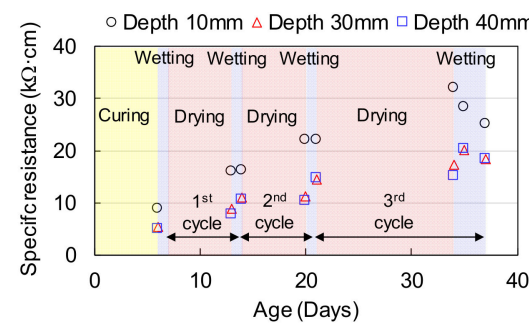

HW45C30

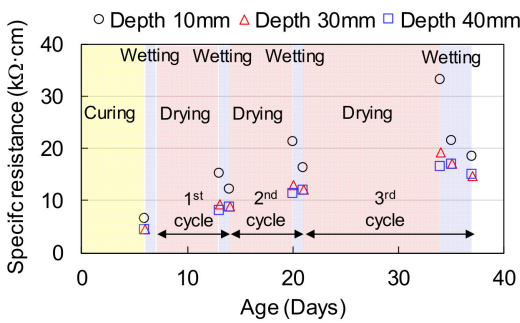

HW60C30

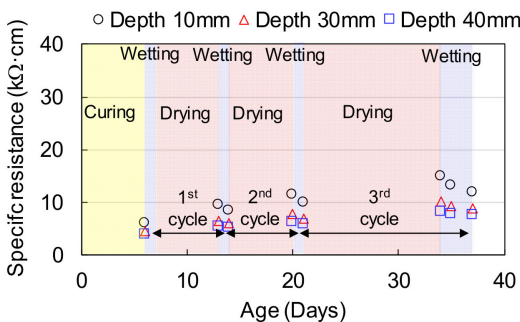

NW60C30

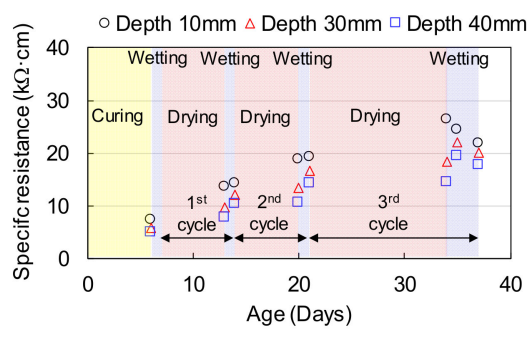

HW45C40

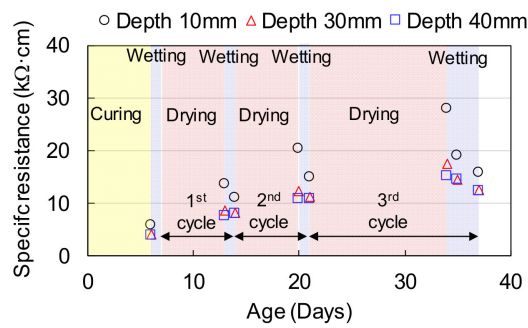

HW60C40

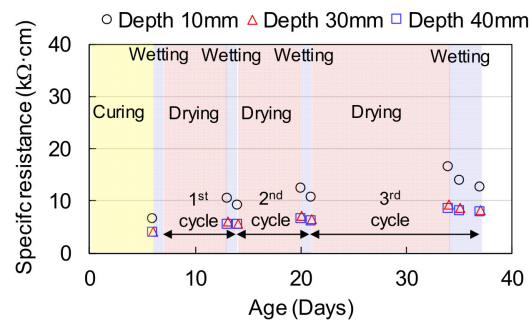

NW60C40

Figure A1. Variation in specific resistance of specimens at each measured depth.

\section{References}

1. ISO 16024:2000. Durability—Service Life Design of Concrete Structures; International Organization for Standardization: Geneva, Switzerland, 2012.

2. FIB. Model Code for Service Life Design (Fib Bulletin No. 34); Federation Internationale du Beton: Lausanne, Switzerland, 2006.

3. Japan Society of Civil Engineers. Standard Specifications for Concrete Structures-2007 (Design); Japan Society of Civil Engineers: Tokyo, Japan; Available online: http:/ / www.jsce.or.jp/committee/concrete/e/newsletter/std2007/sub2.html (accessed on 27 May 2021).

4. Tuutti, K. Service Life of Structures with Regard to Corrosion of Embedded Steel. Am. Concr. Inst. SP 1980, 65, $223-236$. 
5. González, J.A.; Algaba, J.S.; Andrade, C. Corrosion of Reinforcing Bars in Carbonated Concrete. Br. Corros. J. 1980, 15, 135-139. [CrossRef]

6. Glass, G.; Page, C.; Short, N. Factors Affecting the Corrosion Rate of Steel in Carbonated Mortars. Corros. Sci. 1991, 32, 1283-1294. [CrossRef]

7. Stefanoni, M.; Angst, U.; Elsener, B. Corrosion Rate of Carbon Steel in Carbonated Concrete-A Critical Review. Cem. Concr. Res. 2018, 103, 35-48. [CrossRef]

8. Volkwein, A.; Springenschmid, R. Corrosion of Reinforcement in Concrete Bridges at Different Ages Due to Carbonation and Chloride Penetration. Proc. Sec. Int. Conf. Durab. Build. Mater. Compon. 1981, 1981, 199-209.

9. Lollini, F.; Redaelli, E.; Bertolini, L. Corrosion Assessment of Reinforced Concrete Elements of Torre Velasca in Milan. Case Stud. Constr. Mater. 2016, 4, 55-61. [CrossRef]

10. Ishibashi, T.; Furuya, T.; Hamazaki, N.; Suzuki, H. Investigation of Falling on Concrete Fragments from RC Structures. Doboku Gakkai Ronbunshu 2002, 2002, 125-134. [CrossRef]

11. Maehara, S.; Iyoda, T. Study on the Effect of Rain Exposure on Carbonation-Induced Spalling/Falling of the Cover Concrete. J. Jpn. Soc. Civ. Eng. Ser. E2 Mater. Concr. Struct. 2018, 74, 80-87. [CrossRef]

12. Japan Society of Civil Engineers. Standard Specifications for Concrete Structures-2017 (Design); Society of Civil Engineers: Tokyo, Japan, 2017. (In Japanese)

13. Ueda, H.; Sakai, Y.; Kinomura, K.; Watanabe, K.; Ishida, T.; Kishi, T. Durability Design Method Considering Reinforcement Corrosion due to Water Penetration. J. Adv. Concr. Technol. 2020, 18, 27-38. [CrossRef]

14. Thomas, M.D.A.; Matthews, J.D. Carbonation of Fly Ash Concrete. Mag. Concr. Res. 1992, 44, 217-228. [CrossRef]

15. Sulapha, P.; Wong, S.F.; Wee, T.H.; Swaddiwudhipong, S. Carbonation of Concrete Containing Mineral Admixtures. J. Mater. Civ. Eng. 2003, 15, 134-143. [CrossRef]

16. Otieno, M.; Ikotun, J.; Ballim, Y. Experimental Investigations on the Effect of Concrete Quality, Exposure Conditions and Duration of Initial Moist Curing on Carbonation Rate in Concretes Exposed to Urban, Inland Environment. Constr. Build. Mater. 2020, 246, 118443. [CrossRef]

17. Martys, N.S.; Ferraris, C.F. Capillary Transport in Mortars and Concrete. Cem. Concr. Res. 1997, 27, 747-760. [CrossRef]

18. Hall, C. Anomalous Diffusion in Unsaturated Flow: Fact or Fiction? Cem. Concr. Res. 2007, 37, 378-385. [CrossRef]

19. McDonald, P.J.; Istok, O.; Janota, M.; Gajewicz-Jaromin, A.M.; Faux, D.A. Sorption, Anomalous Water Transport and Dynamic Porosity in Cement Paste: A Spatially Localised 1H NMR Relaxation Study and a Proposed Mechanism. Cem. Concr. Res. 2020, 133, 106045. [CrossRef]

20. Japan Meteorological Agency Website. Available online: http://www.data.jma.go.jp/obd/stats/etrn/index.php (accessed on 27 May 2021). (In Japanese)

21. Canty and Associates LLC Website. Available online: https:/ /www.weatherbase.com/ (accessed on 27 May 2021).

22. Railway Technical Research Institute. Maintenance Standards for Railway Structures and Commentary Concrete Structures; Maruzen Publishing Co., Ltd.: Tokyo, Japan, 2007. (In Japanese)

23. Japan Society of Civil Engineers. Standard Specifications for Concrete Structures 2018 (Test Methods and Specifications); Society of Civil Engineers: Tokyo, Japan, 2018.

24. Eddy, L.; Matsumoto, K.; Nagai, K.; Chaemchuen, P.; Henry, M.; Horiuchi, K. Investigation on Quality of Thin Concrete Cover using Mercury Intrusion Porosimetry and Non-Destructive Tests. J. Asian Concr. Fed. 2018, 4, 47-66. [CrossRef]

25. Maekawa, K.; Chaube, R.P.; Kishi, T. Modelling of Concrete Performance; E and FN SPON: London, UK, 1999.

26. Maekawa, K.; Ishida, T.; Kishi, T. Multi-Scale Modeling of Structural Concrete; Taylor \& Francis: London, UK, 2009.

27. Nakarai, K.; Ishida, T.; Kishi, T.; Maekawa, K. Enhanced Thermodynamic Analysis Coupled with Temperature-Dependent Microstructures of Cement Hydrates. Cem. Concr. Res. 2007, 37, 139-150. [CrossRef]

28. Ishida, T.; Maekawa, K.; Kishi, T. Enhanced Modeling of Moisture Equilibrium and Transport in Cementitious Materials under Arbitrary Temperature and Relative Humidity History. Cem. Concr. Res. 2007, 37, 565-578. [CrossRef]

29. Asamoto, S.; Ohtsuka, A.; Kuwahara, Y.; Miura, C. Study on Effects of Solar Radiation and Rain on Shrinkage, Shrinkage Cracking and Creep of Concrete. Cem. Concr. Res. 2011, 41, 590-601. [CrossRef]

30. Rucker-Gramm, P.; Beddoe, R. Effect of Moisture Content of Concrete on Water Uptake. Cem. Concr. Res. 2010, 40, 102-108. [CrossRef]

31. Li, K.; Li, C.; Chen, Z. Influential Depth of Moisture Transport in Concrete Subject to Drying-Wetting Cycles. Cem. Concr. Compos. 2009, 31, 693-698. [CrossRef] 